\title{
Platelet Integrins in Tumor Metastasis: Do They Represent a Therapeutic Target?
}

\author{
Marion Lavergne, Emily Janus-Bell, Mathieu Schaff, Christian Gachet $\mathbb{B}^{\mathbb{D}}$ and Pierre H. Mangin * \\ Université de Strasbourg, INSERM, EFS Grand-Est, BPPS UMR-S 949, FMTS, F-67000 Strasbourg, France; \\ marion.lavergne@efs.sante.fr (M.L.); Emily.Janus-Bell@efs.sante.fr (E.J.-B.); mathieu-schaff@outlook.com (M.S.); \\ christian.gachet@efs.sante.fr (C.G.) \\ * Correspondence: pierre.mangin@efs.sante.fr; Tel.: +33-388-21-25-25
}

Received: 8 September 2017; Accepted: 25 September 2017; Published: 28 September 2017

\begin{abstract}
Platelets are small anucleated cell fragments that ensure the arrest of bleeding after a vessel wall injury. They are also involved in non-hemostatic function such as development, immunity, inflammation, and in the hematogeneous phase of metastasis. While the role of platelets in tumor metastasis has been recognized for 60 years, the molecular mechanism underlying this process remains largely unclear. Platelets physically and functionally interact with various tumor cells through surface receptors including integrins. Platelets express five integrins at their surface, namely $\alpha 2 \beta 1, \alpha 5 \beta 1, \alpha 6 \beta 1, \alpha v \beta 3$, and $\alpha \mathrm{IIb} \beta 3$, which bind preferentially to collagen, fibronectin, laminin, vitronectin, and fibrinogen, respectively. The main role of platelet integrins is to ensure platelet adhesion and aggregation at sites of vascular injury. Two of these, $\alpha 6 \beta 1$ and $\alpha \mathrm{IIb} \beta 3$, were proposed to participate in platelet-tumor cell interaction and in tumor metastasis. It has also been reported that pharmacological agents targeting both integrins efficiently reduce experimental metastasis, suggesting that platelet integrins may represent new anti-metastatic targets. This review focuses on the role of platelet integrins in tumor metastasis and discusses whether these receptors may represent new potential targets for novel anti-metastatic approaches.
\end{abstract}

Keywords: platelets; cancer; integrins; hemostasis; thrombosis; metastasis; antiplatelet agents

\section{The Role of Platelets in Hemostasis and Tumor Metastasis}

Blood platelets are small anucleate cell fragments derived from megakaryocytes. They are major actors in hemostasis, which represents the physiological process preventing spontaneous bleeding and leading to the arrest of blood loss in case of vascular injury [1]. Following vessel injury, platelets adhere to various adhesive proteins exposed by the subendothelium. Under conditions of elevated blood flow, found notably in the microcirculation, platelet recruitment is primarily ensured by the glycoprotein (GP) Ib-IX-V complex, which supports binding to von Willebrand factor (VWF) immobilized in the subendothelium [2]. Integrins have a similar function, allowing the capture of flowing platelets, but this is restricted to low wall shear rate conditions $\left(<1000 \mathrm{~s}^{-1}\right)[3,4]$. Integrins support stable adhesion of platelets and also initiate their activation through outside-in signaling. Platelets express five integrins, namely $\alpha \operatorname{Ilb} \beta 3, \alpha v \beta 3, \alpha 2 \beta 1, \alpha 5 \beta 1$, and $\alpha 6 \beta 1$, which bind preferentially fibrinogen, vitronectin, collagen, fibronectin, and laminins, respectively [5]. Stationary platelet adhesion facilitates the interaction of glycoprotein (GP)VI with collagen [6], which initiates an intracellular signaling cascade, leading notably to the release of the $\delta$-granules content including adenosine di-phosphate (ADP), adenosine tri-phosphate (ATP) [7], and serotonin, and to the synthesis of thromboxane A2 (TxA2). These soluble agonists, together with thrombin, which is generated at the site of injury, potentiate platelet activation, resulting in the upregulation of the affinity of integrin $\alpha \mathrm{Ilb} \beta 3$ for its main ligand, soluble fibrinogen [8]. Fibrinogen forms bridges between adjacent platelets, supporting the 
formation of a plug that seals the breach and stops blood loss [9]. Besides their main role in hemostasis, platelets were proposed to participate in non-hemostatic functions, including development, wound healing, inflammation, angiogenesis, and cancer [10-14].

In 1865, Armand Trousseau clinically recognized the link between cancer and hemostatic abnormalities. He reported cases of thrombophlebitis in patients who were diagnosed with cancer [15]. In 1968, Gasic and collaborators reported the first link between platelets and tumor metastasis. They demonstrated that the ability of inoculated tumor cells to colonize the lung was markedly decreased in thrombocytopenic mice [16]. The link with platelets was even further evidenced after transfusion of platelets which restored metastasis in the thrombocytopenic mice. Besides experimental work, recent clinical studies have also proposed that platelets might participate in tumor metastasis. This mainly results from a meta-analysis of large clinical trials on patients with cardiovascular diseases that highlighted the beneficial effect of the anti-platelet drug aspirin being taken daily, which reduced the incidence of metastasis in adenocarcinomas (stomach, small bowel, pancreas, bileduct, colon, rectum, uterus, ovary, and prostate cancer) and breast cancer $[17,18]$ and notably reduced deaths due to colorectal and gastrointestinal cancers [19].

Numerous studies have tried to define the role of platelets in tumor metastasis. Platelets are likely to be among the first blood cells to interact with tumor cells upon intravasation. It has been reported that the platelet receptors C-type lectin-like receptor 2 (CLEC-2) [20], P-selectin [21], and integrins $\alpha 6 \beta 1$ and $\alpha \operatorname{Ilb} \beta 3[22,23]$ support interaction with tumor cell through the binding of podoplanin, P-selectin glycoprotein ligand-1 (PSGL-1), A disintegrin and metalloproteinase domain-containing protein 9 (ADAM-9), and fibrinogen/ $\alpha \mathrm{v} \beta 3$, respectively. This interaction was proposed to form a physical shield around cancer cells, thereby protecting them from the deleterious effects of shear forces [24]. Platelets have also been proposed to protect the tumor cells from the immune system [25]. This observation was brought to light in a study showing that platelets contribute to metastasis by protecting tumor cells from natural killer (NK) cell lysis [26]. The proposed mechanism could rely on the ability of platelets to secrete agents such as transforming growth factor- $\beta$ (TGF- $\beta$ ) which down-regulates the expression of natural killer group 2 member D (NKG2D) on NK cells, decreasing their cytotoxic effect [27]. An additional mechanism could result from the ability of platelets to transfer a major histocompatibility complex (MHC) class I onto tumor cells to provide a self-signal to NK cells which will suppress their cytotoxic activity on these tumor cells [25]. Beside these protective roles, platelets promote epithelial-mesenchymal transition (EMT), notably by the ability of tumor cell activated platelets to release TGF- $\beta$ [28]. Moreover, it has been shown that platelets facilitate tumor cell adhesion to endothelial cells through a mechanism that could rely on $\alpha \operatorname{IIb} \beta 3$ [29]. Finally, platelets were proposed to play a role in the enhancement of tumor cell extravasation accross the endothelial barrier. This has been reported in a study showing that tumor cell transendothelial migration is allowed thanks to tumor cell-activated platelets release of ATP which induces endothelial barrier opening upon binding the endothelial $\mathrm{P}_{2} \mathrm{Y}_{2}\left(\mathrm{P}_{2} \mathrm{Y}_{2}\right)$ receptor [30]. Platelets could also facilitate tumor cell extravasation after the release of MMPs, which degrades the extracellular matrix. This effect could be direct after the release of matrix metalloproteinase-2 (MMP-2) by activated platelets [31], or indirect through the ability of platelets to stimulate the secretion of MMPs by tumor cells [32] (Figure 1).

While the role of platelets in tumor metastasis has been long recognized and extensively reviewed [13,14,33-35], the underlying molecular mechanism remains largely unknown. This review focuses on the current knowledge about the potential role of platelet integrins in tumor metastasis. We will first provide some general information about integrins expressed on platelets and highlight their main known functions. We will also summarize the experimental evidence that has been reported concerning their involvement in physical and functional interaction with tumor cells and describe their proposed role in experimental tumor metastasis. Finally, we will discuss whether platelet integrins could represent a novel and interesting anti-metastatic target. 


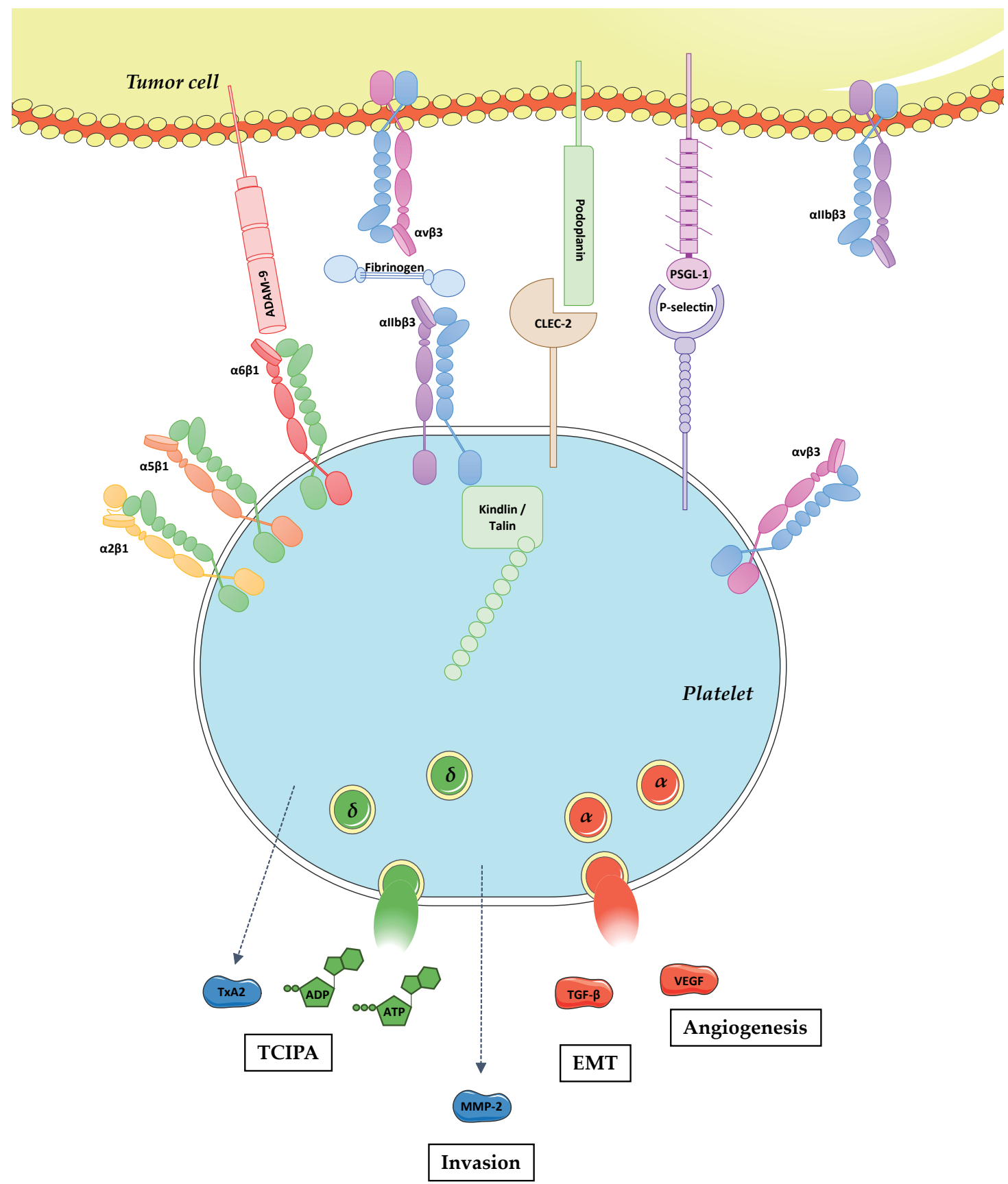

Figure 1. Physical and functional platelet-tumor cell crosstalk. Tumor metastasis is a complex process including the detachment of tumor cells from the primary tumor, intravasation, survival in the bloodstream, extravasation, and proliferation at the distant site. Following intravasation, tumor cells enter into the bloodstream and get in close contact with various circulating blood cells including platelets. Platelets physically interact with tumor cells through the binding of CLEC-2, P-selectin, and integrins $\alpha 6 \beta 1$ and $\alpha \mathrm{IIb} \beta 3$ with podoplanin, PSGL-1, ADAM- 9 and fibrinogen/ $\alpha \mathrm{v} \beta 3$, respectively. The role of platelet integrins $\alpha 2 \beta 1, \alpha 5 \beta 1$, and $\alpha \mathrm{v} \beta 3$ in direct interaction with tumor cells remains unknown. Platelet adhesion to tumor cells results in their activation, which promotes: (i) platelet shape change; (ii) integrin $\alpha \mathrm{IIb} \beta 3$ activation upon talin and kindlin binding to the intracytoplasmic domain of the $\beta 3$ chain; (iii) the release of biologically active molecules including TxA2, ADP, ATP, MMP-2, TGF- $\beta$, and Vascular endothelial growth factor (VEGF). In turn, these mediators promote: (i) Tumor cell induced platelet aggregation (TCIPA); (ii) tumor cell invasion; (iii) EMT; and (iv) angiogenesis. 


\section{The Repertoire and Function of Integrins at the Platelet Surface}

Platelets express five distinct types of integrins at their surface which belong either to the $\beta 1$ or the $\beta 3$ family. The best-known function of platelet integrins is to ensure the adhesive properties of platelets through their interaction with plasma or subendothelial proteins [36]. Integrins oscillate between various structural conformations going from a low to more elevated affinity state for their ligands [37,38]. In resting platelets, integrins are recognized to be in a relatively low-affinity state for their ligands and are unable to efficiently bind them in suspension. However, when those ligands including fibrinogen, collagen, fibronectin, or laminins are immobilized on a surface, platelet integrins support the recruitment of resting discoid platelets under low blood flow conditions $\left(<1000 \mathrm{~s}^{-1}\right)$. This observation indicates that even in resting platelets, at least one pool of surface expressed integrins has a sufficient activation status allowing them to bind their ligands [2,3]. To move from a low to a high affinity state, integrins become activated by a so-called inside-out signaling arising from stimulation by soluble mediators (ADP, TxA2, thrombin) or adhesive proteins (collagen, VWF) $[39,40]$. These signaling cascades activate heterotrimeric $G$ proteins or tyrosine kinases leading to phospholipase $C$ (PLC) $-\beta$ or $-\gamma$ activation, increase in intracellular levels of $\mathrm{Ca}^{2+}$ and lead to the activation of $\mathrm{Ca}^{2+}$ and diacylglycerol-regulated guanine-nucleotide-exchange factor I (CalDAG-GEFI) and Rap1b [41]. This results, at least for $\alpha \mathrm{IIb} \beta 3$, is the binding of talin- 1 and kindlin- 3 to the cytoplasmic tail of the $\beta$ chain, triggering a conformational change in the extracellular domain resulting in a shift from a low to a high affinity state of the integrin for its ligands [42]. In turn, ligand binding to the integrins generates an outside-in signal that mainly reinforce platelet activation (see below).

\subsection{The Platelet $\beta 1$ Integrins}

Members of the $\beta 1$ integrin family are ubiquitously expressed and found notably on lymphocytes, epithelial, endothelial and smooth muscle cells (SMCs). Integrins $\beta 1$ are involved in hallmarks of cancer and particularly in survival, cell death control, and invasion of tumor cells [43].

Platelets express three members of this family of proteins, namely $\alpha 2 \beta 1, \alpha 5 \beta 1$, and $\alpha 6 \beta 1$, which bind collagen, fibronectin, and laminins, respectively. These integrins are expressed at relatively low levels on the platelet surface reaching a couple of thousands molecules per cell [5]. Even though no precise quantification has been reported, $\alpha 6 \beta 1$ has probably the highest copy number per platelet compared to the other two $\beta 1$ integrins [44].

\subsection{1. $\alpha 2 \beta 1$}

Integrin $\alpha 2 \beta 1$ is expressed by platelets, fibroblasts, epithelial, and endothelial cells [45]. It senses many different extracellular matrix proteins including collagen and laminins. This integrin plays a role in various processes including immunity, development, and cancer [46]. Integrin $\alpha 2$ gene polymorphisms were shown to be associated with breast and colorectal cancer risk [47-49].

On platelets, integrin $\alpha 2 \beta 1$ is a receptor for collagen which mainly supports the stable adhesion of platelets [50]. Because of a polymorphism, its surface expression varies between 2000 and 8000 copies per platelet [51]. Ligand binding to $\alpha 2 \beta 1$ generates outside-in signals involving Src kinases, Syk, the adapter protein SLP-76 and leading to PLC- $\gamma 2$ activation and subsequent mobilization of internal stores of $\mathrm{Ca}^{2+}$ [52]. Integrin $\alpha 2 \beta 1$ does not appear to play a crucial role in hemostasis. Indeed, two patients with genetic defects in $\alpha 2 \beta 1$ exhibit only a moderate bleeding phenotype [53,54]. These results are in agreement with a mouse model deficient for $\alpha 2 \beta 1$ that did not show a prolonged tail-bleeding time [55]. The use of knock-out mice helped to identify a role for integrin $\alpha 2 \beta 1$ in experimental thrombosis. Interestingly, this integrin appears to be involved at the blood-vessel wall interface as well as in the process of thrombus stability $[56,57]$. Studies performed in our laboratory did not conclude that there was a major role of $\alpha 2 \beta 1$ in two models of experimental thrombosis based on mechanical injury of the aorta and $\mathrm{FeCl}_{3}$ injury of the carotid artery, suggesting that this integrin most likely plays a subtle role in experimental thrombosis (Mangin, unpublished results, 2015). Polymorphisms shown 
to increase the expression level of $\alpha 2 \beta 1$ and platelet adhesiveness were also proposed as risk factors for thrombotic events [58]. No other role for platelet $\alpha 2 \beta 1$ has been reported to date.

\subsection{2. $\alpha 5 \beta 1$}

Integrin $\alpha 5 \beta 1$ is ubiquitously expressed and best known as a receptor for fibronectin, playing an important role in cell migration and differentiation especially during development [59]. For this reason, $\alpha 5$ deletion in mice is lethal at the embryonic stage, which has precluded the investigation of its function in various cells including platelets [60]. Integrin $\alpha 5 \beta 1$ is overexpressed in several cancers, including colon, breast, ovarian, lung, and brain tumors, and is associated with a poor prognosis [61]. It has been proposed that targeting $\alpha 5 \beta 1$ expressed on tumor cells might reduce the metastasis of head and neck cancers [62]. Clinical trials on the anti- $\alpha 5 \beta 1$ chimeric antibody, M200 (Volociximab), have shown it to be generally well tolerated, with some preliminary evidence of efficacy in advanced non-small-cell lung cancer [63].

Concerning platelets, it has been reported that $\alpha 5 \beta 1$ supports modest platelet adhesion and activation to immobilized soluble fibronectin under both static and flow conditions [64-66]. We have previously shown that $\alpha 5 \beta 1$-mediated platelet adhesion and activation becomes much more significant when platelets are perfused over cellular fibronectin in its fibrillar form, as found in the vessel wall [67]. The role of platelet $\alpha 5 \beta 1$ in hemostasis, arterial thrombosis, and beyond remains to be established.

\subsection{3. $\alpha 6 \beta 1$}

Integrin $\alpha 6 \beta 1$ is a ubiquitous receptor for laminins that is notably known to structure epitheliums [68]. Patients with a deficiency in the $\alpha 6$ gene suffer from a painful disease called epidermolysis bullosa [69], which is a rare genetic connective tissue disorder characterized by blistering of the skin [70]. $\alpha 6 \beta 1$ has also been reported to be overexpressed in breast and prostate cancer and in glioblastoma [71-73]. It was proposed to favor tumor cell survival as well as tumor metastasis [74,75].

Concerning platelets, several studies have shown that $\alpha 6 \beta 1$ supports platelet adhesion to laminins under both static and flow conditions [76-80]. This interaction generates outside-in signals involving the tyrosine kinase Syk, PLC- $\gamma 2$, Phosphoinositide 3-kinase (PI3K), and Cdc42, leading to morphological changes in platelets $[77,81,82]$. By using tissue-specific $\alpha 6 \beta 1$-deficient mice we showed that this integrin supports platelet adhesion to vascular laminins even under high wall shear rate conditions. Moreover, $\alpha 6 \beta 1$ is not essential for normal hemostasis but plays an important role in experimental thrombosis [44]. We have also established a role for this platelet integrin in tumor metastasis (see Section 3.1).

\subsection{The Platelet $\beta 3$ Integrins}

$\alpha v \beta 3$ and $\alpha \mathrm{Ilb} \beta 3$ are the two members of the $\beta 3$ integrin family. $\alpha v \beta 3$ is expressed on osteoclasts and endothelial cells, while $\alpha \mathrm{IIb} \beta 3$ is mainly found in platelets [83]. Both integrins have been described to be expressed in tumor cells $[22,84-86]$. While the role of $\alpha \mathrm{Ilb} \beta 3$ in tumor cells remains unclear, the importance of $\alpha \mathrm{v} \beta 3$ has been much better defined. The expression level of $\alpha \mathrm{v} \beta 3$ integrin is correlated to a metastatic phenotype in cervical, ovarian, pancreatic, prostate, and breast cancer, glioblastoma, and melanoma [87]. $\alpha v \beta 3$ is involved in many steps of the tumor progression as well as in endothelial cell survival to allow angiogenesis [88], migration, and metastasis [89,90].

\subsection{1. $\alpha \operatorname{Ilb} \beta 3$}

Integrin $\alpha \mathrm{IIb} \beta 3$ was long believed to be specifically expressed in the platelet lineage, but has also been reported to be present in several tumor cells [22,84-86], promoting tumor cell adhesion and invasion $[22,85,86,91]$. Integrin $\alpha \operatorname{IIb} \beta 3$ is the most abundant receptor on platelets, with 50,000 copies at the surface and 30,000 more in the open canalicular system and $\alpha$-granules that are exposed upon platelet activation [92]. $\alpha \mathrm{Ilb} \beta 3$ notably recognizes RGD peptide-binding sequence on various adhesive proteins including fibrinogen, VWF, fibronectin, and vitronectin. The major role of $\alpha \mathrm{Ilb} \beta 3$ 
is to ensure platelet aggregation through the binding of plasma fibrinogen, whose dimeric nature allows the bridging of adjacent platelets [36]. This process requires $\alpha \mathrm{IIb} \beta 3$ to be in an activated state. The physiological importance of $\alpha \mathrm{Ilb} \beta 3$ is evidenced by a bleeding diathesis called Glanzmann's thrombosthenia, which results from a deficiency of the integrin and is characterized by a defect in platelet aggregation [93]. $\alpha \mathrm{Ilb} \beta 3$ is also a target for a class of anti-thrombotic drugs used in acute settings such as during myocardial infarction and percutaneous coronary interventions [94].

Fibrinogen binding to $\alpha \mathrm{IIb} \beta 3$ induces its clustering and initiates outside-in signaling that has been extensively studied. This signaling cascade was proposed to involve Src kinases, Syk, SLP-76, PI3K p110- $\beta$ and $-\delta$, and leads to the activation of PLC- $\gamma 2$ and Rap1b $[95,96]$. Outside-in signaling reinforces the signal leading to $\alpha \operatorname{Ilb} \beta 3$ activation, and is also responsible for morphological changes of platelets, granule secretion and clot retraction. It plays an important role in the stabilization of aggregates and is central in both hemostasis and experimental thrombosis [97-101].

\subsection{2. $\alpha v \beta 3$}

Integrin $\alpha v \beta 3$ is mainly found in endothelial cells, SMCs, and platelets [59]. Its structure is closely related to that of $\alpha \mathrm{Ilb} \beta 3$ and recognizes RGD peptide-binding sequence in several adhesive proteins including fibrinogen, fibronectin, VWF, and vitronectin. Only several hundred copies of $\alpha \mathrm{V} \beta 3$ are found at the platelet surface. It has been proposed that $\alpha \mathrm{v} \beta 3$ supports modest platelet adhesion to both fibronectin and vitronectin [66,102] and might participate in clot retraction [103]. Its importance in hemostasis and arterial thrombosis has not yet been reported. Recent unpublished results from our group indicate that $\alpha \mathrm{V} \beta 3$ plays a minor role in both processes as evidenced by a normal tail-bleeding time and no impact on experimental thrombosis in a mouse strain knocked out for this integrin in the platelet lineage (PF4-Cre- $\alpha \mathrm{v}^{-/-}$), (Pierre Mangin, Catherine Léon, unpublished results, 2016).

\section{The Role of Platelet Integrins in the Interplay with Tumor Cells and in Tumor Metastasis}

\subsection{The $\beta 1$ Integrins}

Based on both experimental and spontaneous models, we have recently reported that platelet integrin $\alpha 6 \beta 1$ supports tumor metastasis [23]. The role of this integrin appears to be linked to its ability to directly interact with various types of tumor cells through the binding of ADAM-9 [104]. We provided evidence that this interaction is important in the process of tumor cell extravasation. We hypothesize that the decreased physical interaction of platelets with tumor cells reduces the number of agents released by platelets, including secreted ATP, which is known to facilitate extravasation through acting on endothelial P2 $Y_{2}$ [30]. Whether the other members of the $\beta 1$ integrin family, $\alpha 2 \beta 1$, and $\alpha 5 \beta 1$, also participate in metastasis is still unknown. We could speculate that integrins probably do not play a crucial role in this process, based on the observation that the level of inhibition of tumor cell colonization to the lungs was very similar in mice deficient for platelet $\alpha 6 \beta 1$ when compared to mice deficient for all three $\beta 1$ integrins (PF4-Cre- $\beta 1^{-/-}$) [23]. However, experimental evidence is needed to precisely assess the potential role of platelet $\alpha 2 \beta 1$ and $\alpha 5 \beta 1$ in tumor metastasis.

\subsection{The $\beta 3$ Integrins}

Seminal studies have shown that $\beta 3$ antagonists such as blocking antibodies or RGD-containing peptides inhibit the physical interaction between platelets and tumor cells, allowing the authors to suggest that platelet $\alpha \mathrm{Ilb} \beta 3$ ensures the direct binding of platelets with tumor cells [22,105-107]. However, because $\alpha \mathrm{IIb} \beta 3$ was also reported to be expressed in tumor cells $[22,84-86]$ and has even been proposed to mediate the direct interaction with platelets [108], the implication and the relative importance of platelet versus tumor cell $\alpha \operatorname{Ilb} \beta 3$ in the physical interaction of these cells long remained unclear $[91,109]$. Since then, the use of platelets from Glanzmann's thrombasthenic patients, who lack functional $\alpha \mathrm{IIb} \beta 3$, allowed confirmation of the role of this integrin in direct platelet/tumor cell interaction in a static adhesion assay [22,29]. Flow-based assays indicated that $\alpha \mathrm{Ilb} \beta 3$ facilitates the 
stable adhesion of tumor cells on immobilized platelets, a function that is well known to be ensured by this integrin on various adhesive proteins [110]. Additional studies showed that platelet $\alpha \mathrm{IIb} \beta 3$ supports interaction with tumor cells through $\alpha \mathrm{v} \beta 3$ in a process relying on fibrinogen, which could bridge both integrins [29,111-113]. While it is clear that tumor cell binding to platelets promotes activation, as evidenced by shape change, granule content secretion, or TxA2 release [34,114-123], it is rather challenging to evaluate the importance of $\alpha \operatorname{Ilb} \beta 3$ in this process relative to other platelet receptors binding to tumor cells. This is even more challenging if we assume that the physical links between platelets and tumor cells depends on the repertoire of receptors expressed on different tumor cells. Nevertheless, Amirkhosravi and colleagues proposed that tumor cell binding to platelet $\alpha \mathrm{IIb} \beta 3$ promotes their activation and induces the release of VEGF, which can act on tumor cells to regulate their function [124].

Platelet integrin $\alpha \operatorname{Ilb} \beta 3$ has been reported to play a central role in the process of TCIPA [125-128]. This observation is not a surprise because $\alpha \mathrm{Ilb} \beta 3$ is a key receptor supporting platelet aggregation [36]. While the primum movens of TCIPA remains elusive, one could speculate that platelet $\alpha \operatorname{IIb} \beta 3$ participates at least partially because of its ability to ensure the physical interaction with tumor cells $[127,129]$. The process of TCIPA has been extensively studied and well characterized. In addition to $\alpha \mathrm{IIb} \beta 3$, it is supported by other platelet surface receptors such as the GPIb-IX-V complex and CLEC-2 and triggered by soluble agonists including ADP and TxA2, which are released from activated platelets $[20,122,126,130-133]$. TCIPA also relies on thrombin generation, even though the role of this serine protease largely depends on the experimental conditions $[115,132,134-137]$. Several studies have shown a correlation between TCIPA and tumor metastasis $[85,118,128,138-144]$. This is now widely accepted since many publications refer to this link, even though the detailed analysis of the seminal papers mainly show indirect links, with a paucity of experimental evidence (Figure 1).

It has been convincingly reported that $\alpha \mathrm{Ilb} \beta 3$ blockers impair experimental metastasis [145-147]. However, whether these inhibitors mediate their effect by acting on platelet or tumor cell $\alpha \operatorname{IIb} \beta 3$ integrins has long been unclear. Moreover, several $\alpha \operatorname{IIb} \beta 3$ blockers are not specific $[148,149]$ and also target $\alpha v \beta 3$, which is expressed in many tumor cells and well known to participate in cancer cell function and metastasis [87]. One of the most convincing studies supporting a role of platelet $\alpha \operatorname{IIb} \beta 3$ in metastasis came from Bakewell and collaborators, who showed that transfer of $\beta 3^{-/-}$ bone marrow in irradiated wild-type mice confers protection towards osteolytic metastasis [146]. However, this result has recently been challenged using $\alpha \mathrm{Illb}$-deficient mice [150]. While the authors observed a marked reduction of tumor cell accumulation into the lungs of $\alpha \mathrm{Ilb}^{-/-}$mice several hours post-inoculation with the presence of smaller tumor cell clusters, tumor progression at late stages was markedly increased as compared to the wild type. This observation, which will require confirmation, also challenges the link between TCIPA and tumor metastasis.

The role of platelet $\alpha \mathrm{v} \beta 3$ in the physical and functional interaction with tumor cells as well as in experimental metastasis remains largely unclear. Given the very low number of copies of $\alpha \mathrm{v} \beta 3$ on the platelet surface, it is unlikely that this integrin plays a major role in this process, but a definitive answer cannot be reached without experimental evidence.

\section{Is Targeting Platelet Integrins a Potentially Promising Anti-Metastatic Strategy?}

Concerning $\beta 1$ integrins, we have reported that platelet $\alpha 6 \beta 1$, but probably not $\alpha 2 \beta 1$ and $\alpha 5 \beta 1$, participates in tumor metastasis [23]. Moreover, we provided evidence that a pharmacological approach based on blockade of $\alpha 6 \beta 1$ with GoH3, an antibody, reduced experimental metastasis, suggesting that this integrin represents an interesting target for anti-metastatic therapy. Importantly, administration of the blocking antibody did not induce thrombocytopenia and did not impair hemostasis, suggesting that such an approach might not be associated with an elevated bleeding risk. However, because $\alpha 6 \beta 1$ is not just expressed on platelets, preclinical studies appear mandatory to evaluate the long-term impact of an anti- $\alpha 6 \beta 1$ agent. On the one hand, one could speculate that such treatment might be beneficial and could further reduce metastasis since $\alpha 6 \beta 1$ is notably expressed by 
endothelial and tumor cells, in which it participates in cancer progression [74,75]. On the other hand, targeting $\alpha 6$ might have deleterious effects because this integrin is ubiquitously expressed and plays various roles, notably in epithelial cell anchoring. As an example, a lack of $\alpha 6$ expression has been shown to result in hemidesmosome deficiency and be responsible for skin and mucous membrane disorders, including pyloric atresia and epidermolysis bullosa [69]. Whether a pharmacological approach in patients could induce such pathologies linked to development is uncertain but will clearly need to be evaluated in preclinical and clinical studies.

It is recognized that integrin $\alpha \mathrm{Ilb} \beta 3$ plays a central role in both TCIPA and tumor metastasis and that there is a potential link between both processes [151]. It has also been shown that various $\alpha \operatorname{Ilb} \beta 3$ blockers efficiently reduce experimental metastasis, allowing numerous groups to speculate that this integrin represents an attractive target to limit tumor metastasis $[22,145,147,152]$. $\alpha \operatorname{IIb} \beta 3$ blockers, including Abciximab, Eptifibatide, and Tirofiban, are already in clinical use as potent anti-thrombotic drugs [153] (Table 1). These agents are administered intravenously and their use is strictly restricted to acute settings such as percutaneous coronary interventions and acute coronary syndromes (ACS) because of their elevated risk of bleeding. It is therefore not conceivable to use such agents in the long term to prevent tumor metastasis. There have been attempts to develop orally active $\alpha \mathrm{Ilb} \beta 3$ blockers, based on an RGD peptide-binding sequence. Unfortunately, the clinical trial was stopped before completion because of a non-significant benefit for patients with an ACS and an increase in mortality [154]. The underlying mechanism appears to be linked to the ability of these antagonists to activate $\alpha \mathrm{IIb} \beta 3$ through fibrinogen mimetic action on the ligand-induced binding site (LIBS) [155]. As a consequence, the development of new oral anti- $\alpha \operatorname{Ilb} \beta 3$ agents was stopped. While the interest in developing novel anti- $\alpha \mathrm{IIb} \beta 3$ dropped, it has been postulated that the strategy rather than the target is inappropriate [156-158]. Contrary to anti- $\alpha \operatorname{Ilb} \beta 3$, the use of agents targeting only the activated form of $\alpha \mathrm{Ilb} \beta 3$ could be used at much lower systemic concentrations since they specifically accumulate at sites of platelet activation, therefore improving their safety profile. Among these new strategies (Table 1), one consists of targeting the active form of $\alpha \operatorname{IIb} \beta 3$ with a single-chain antibody (scFvMA2) that exclusively recognizes the active conformation of $\alpha \mathrm{IIb} \beta 3$ [158]. Another innovative agent, RUC-4, is a small molecule identified through high-throughput screening that targets the metal ion-dependent adhesion site (MIDAS) site of $\beta 3$, presenting the advantage of preventing the high-affinity ligand-binding conformation change of the integrin [159]. Finally, a more recent strategy aims to target the plexin-semaphorin-integrin (PSI) involved in the Protein Disulfide Isomerase (PDI)-like activity of $\beta 3$ integrin, which inhibits PDI-like activity and fibrinogen binding [160]. Whether these innovative agents exhibit a protective effect in mouse models of experimental metastasis is not yet known and will need to be investigated. 
Table 1. Anti- $\alpha \operatorname{Ilb} \beta 3$ agents.

\begin{tabular}{|c|c|c|c|c|c|c|}
\hline Name & Nature of the Agent & Use & $\begin{array}{l}\text { Inhibition } \\
\text { of Platelet } \\
\text { Aggregation }\end{array}$ & $\begin{array}{l}\text { Inhibition } \\
\text { of in Vivo } \\
\text { Thrombus } \\
\text { Formation }\end{array}$ & $\begin{array}{c}\text { Activatory } \\
\text { Effect on } \\
\alpha \operatorname{IIb} \beta 3\end{array}$ & $\begin{array}{l}\text { Effect on } \\
\text { Bleeding }\end{array}$ \\
\hline $\begin{array}{l}\text { Abciximab } \\
\left.\text { (ReoPro }^{\circledR}\right)\end{array}$ & $\begin{array}{l}\text { chimeric Fab fragment } \\
\text { derived from the } \\
\text { murine monoclonal } \\
\text { antibody 7E3 }\end{array}$ & Clinically used & $\sqrt{ }$ & $\sqrt{ }$ & $\sqrt{ }$ & $\sqrt{ }$ \\
\hline $\begin{array}{c}\text { Tirofiban } \\
\left.\text { (Aggrastat }^{\circledR}\right)\end{array}$ & $\begin{array}{l}\text { non-peptide agent } \\
\text { based on the RGD } \\
\text { sequence }\end{array}$ & Clinically used & $\sqrt{ }$ & $\sqrt{ }$ & $\sqrt{ }$ & $\sqrt{ }$ \\
\hline $\begin{array}{l}\text { Eptifibatide } \\
\text { (Integrilin }^{\circledR} \text { ) }\end{array}$ & $\begin{array}{l}\text { KGD-containing cyclic } \\
\text { heptapeptide }\end{array}$ & Clinically used & $\sqrt{ }$ & $\sqrt{ }$ & $\sqrt{ }$ & $\sqrt{ }$ \\
\hline RUC-4 & $\begin{array}{l}\text { Low-molecular weight } \\
\text { molecule }\end{array}$ & $\begin{array}{l}\text { Used in } \\
\text { pre-clinical } \\
\text { studies }\end{array}$ & $\sqrt{ }$ & $\sqrt{ }$ & $x$ & $\begin{array}{c}\text { Not } \\
\text { evaluated }\end{array}$ \\
\hline scFv MA2 & $\begin{array}{l}\text { Single-chain antibody } \\
\text { directed against the } \\
\text { activated form } \\
\text { of } \alpha \operatorname{Ilb} \beta 3\end{array}$ & $\begin{array}{l}\text { Used in } \\
\text { pre-clinical } \\
\text { studies }\end{array}$ & $\sqrt{ }$ & $\sqrt{ }$ & $x$ & $\begin{array}{l}\text { No impact } \\
\text { on mouse } \\
\text { tail-bleeding } \\
\text { time }\end{array}$ \\
\hline$\underset{\text { anti-PSI }}{\operatorname{mAb}}$ & $\begin{array}{c}\text { Monoclonal antibody } \\
\text { against the } \beta 3 \text { PSI } \\
\text { domain }\end{array}$ & $\begin{array}{l}\text { Used in } \\
\text { pre-clinical } \\
\text { studies }\end{array}$ & $\sqrt{ }$ & $\sqrt{ }$ & $x$ & $\begin{array}{l}\text { No impact } \\
\text { on mouse } \\
\text { tail-bleeding } \\
\text { time }\end{array}$ \\
\hline
\end{tabular}

\section{Conclusions}

Platelet integrins, mainly $\alpha 6 \beta 1$ and $\alpha \operatorname{Ilb} \beta 3$, have been shown to participate in the hematogeneous phase of metastasis. The main known role of these integrins is to support the physical interaction between platelets and tumor cells and to regulate their function. The relative importance of these glycoproteins compared to other platelet receptors involved in metastasis is still unclear. Experimental evidence has been provided that targeting these receptors efficiently reduces tumor cell colonization into the lungs, suggesting that they could represent interesting targets for anti-metastatic drugs. A clear drawback of targeting $\alpha 6$ is that this integrin is ubiquitously expressed and a pharmacological approach could have unwanted side effects. This will need to be evaluated in pre-clinical and clinical studies. The main drawback for $\alpha \mathrm{Ilb} \beta 3$ is its key role in hemostasis. While acute treatment can be used in the setting of arterial thrombosis, it is impossible to consider long-term treatment with current clinically used anti- $\alpha \mathrm{IIb} \beta 3$ drugs. Future development of more specific agents targeting only activated forms of this integrin, which have a minimal effect on hemostasis, might be interesting but will first need to demonstrate protection towards metastasis in animal models.

Acknowledgments: Marion Lavergne is supported by INCa PLBIO Grant 2016-164: R16003MP.

Author Contributions: Marion Lavergne, Emily Janus-Bell, Mathieu Schaff, Christian Gachet, and Pierre H. Mangin wrote the paper.

Conflicts of Interest: The authors declare no conflict of interest.

\section{References}

1. Versteeg, H.H.; Heemskerk, J.W.; Levi, M.; Reitsma, P.H. New fundamentals in hemostasis. Physiol. Rev. 2013, 93, 327-358. [CrossRef] [PubMed]

2. Savage, B.; Saldivar, E.; Ruggeri, Z.M. Initiation of platelet adhesion by arrest onto fibrinogen or translocation on von Willebrand factor. Cell 1996, 84, 289-297. [CrossRef]

3. Ikeda, Y.; Handa, M.; Kawano, K.; Kamata, T.; Murata, M.; Araki, Y.; Anbo, H.; Kawai, Y.; Watanabe, K.; Itagaki, I.; et al. The role of von Willebrand factor and fibrinogen in platelet aggregation under varying shear stress. J. Clin. Investig. 1991, 87, 1234-1240. [CrossRef] [PubMed] 
4. Reininger, A.J. Platelet function under high shear conditions. Hamostaseologie 2009, 29, 21-24. [PubMed]

5. Bergmeier, W.; Hynes, R.O. Extracellular matrix proteins in hemostasis and thrombosis. Cold Spring Harb. Perspect. Biol. 2012, 4, a005132. [CrossRef] [PubMed]

6. Nieswandt, B.; Watson, S.P. Platelet-collagen interaction: Is GPVI the central receptor? Blood 2003, 102, 449-461. [CrossRef] [PubMed]

7. Hechler, B.; Gachet, C. Purinergic Receptors in Thrombosis and Inflammation. Arterioscler. Thromb. Vasc. Biol. 2015, 35, 2307-2315. [CrossRef] [PubMed]

8. Shattil, S.J.; Newman, P.J. Integrins: Dynamic scaffolds for adhesion and signaling in platelets. Blood 2004, 104, 1606-1615. [CrossRef] [PubMed]

9. Jackson, S.P.; Nesbitt, W.S.; Kulkarni, S. Signaling events underlying thrombus formation. J. Thromb. Haemost. 2003, 1, 1602-1612. [CrossRef] [PubMed]

10. Nurden, A.T. Platelets, inflammation and tissue regeneration. Thromb. Haemost. 2011, 105, S13-S33. [CrossRef] [PubMed]

11. Rondina, M.T.; Garraud, O. Emerging evidence for platelets as immune and inflammatory effector cells. Front. Immunol. 2014, 5, 653. [CrossRef] [PubMed]

12. Walsh, T.G.; Metharom, P.; Berndt, M.C. The functional role of platelets in the regulation of angiogenesis. Platelets 2015, 26, 199-211. [CrossRef] [PubMed]

13. Mammadova-Bach, E.; Mangin, P.; Lanza, F.; Gachet, C. Platelets in cancer. From basic research to therapeutic implications. Hamostaseologie 2015, 35, 325-336. [CrossRef] [PubMed]

14. Leblanc, R.; Peyruchaud, O. Metastasis: New functional implications of platelets and megakaryocytes. Blood 2016, 128, 24-31. [CrossRef] [PubMed]

15. Varki, A. Trousseau's syndrome: Multiple definitions and multiple mechanisms. Blood 2007, 110, $1723-1729$. [CrossRef] [PubMed]

16. Gasic, G.J.; Gasic, T.B.; Stewart, C.C. Antimetastatic effects associated with platelet reduction. Proc. Natl. Acad. Sci. USA 1968, 61, 46-52. [CrossRef] [PubMed]

17. Rothwell, P.M.; Wilson, M.; Price, J.F.; Belch, J.F.; Meade, T.W.; Mehta, Z. Effect of daily aspirin on risk of cancer metastasis: A study of incident cancers during randomised controlled trials. Lancet 2012, 379, 1591-1601. [CrossRef]

18. Shiao, J.; Thomas, K.M.; Rahimi, A.S.; Rao, R.; Yan, J.; Xie, X.-J.; DaSilva, M.; Spangler, A.; Leitch, M.; Wooldridge, R.; et al. Aspirin/antiplatelet agent use improves disease-free survival and reduces the risk of distant metastases in Stage II and III triple-negative breast cancer patients. Breast Cancer Res. Treat. 2017, 161, 463-471. [CrossRef] [PubMed]

19. Rothwell, P.M.; Fowkes, F.G.; Belch, J.F.; Ogawa, H.; Warlow, C.P.; Meade, T.W. Effect of daily aspirin on long-term risk of death due to cancer: Analysis of individual patient data from randomised trials. Lancet 2011, 377, 31-41. [CrossRef]

20. Suzuki-Inoue, K.; Kato, Y.; Inoue, O.; Kaneko, M.K.; Mishima, K.; Yatomi, Y.; Yamazaki, Y.; Narimatsu, H.; Ozaki, Y. Involvement of the snake toxin receptor CLEC-2, in podoplanin-mediated platelet activation, by cancer cells. J. Biol. Chem. 2007, 282, 25993-26001. [CrossRef] [PubMed]

21. Gong, L.; Cai, Y.; Zhou, X.; Yang, H. Activated platelets interact with lung cancer cells through P-selectin glycoprotein ligand-1. Pathol. Oncol. Res. 2012, 18, 989-996. [CrossRef] [PubMed]

22. Boukerche, H.; Berthier-Vergnes, O.; Tabone, E.; Dore, J.F.; Leung, L.L.; McGregor, J.L. Platelet-melanoma cell interaction is mediated by the glycoprotein Ilb-IIIa complex. Blood 1989, 74, 658-663. [PubMed]

23. Mammadova-Bach, E.; Zigrino, P.; Brucker, C.; Bourdon, C.; Freund, M.; de Arcangelis, A.; Abrams, S.I.; Orend, G.; Gachet, C.; Mangin, P.H. Platelet integrin $\alpha 6 \beta 1$ controls lung metastasis through direct binding to cancer cell-derived ADAM9. JCI Insight 2016, 1, e88245. [CrossRef] [PubMed]

24. Tesfamariam, B. Involvement of platelets in tumor cell metastasis. Pharmacol. Ther. 2016, 157, 112-119. [CrossRef] [PubMed]

25. Placke, T.; Kopp, H.G.; Salih, H.R. The wolf in sheep's clothing: Platelet-derived "pseudo self" impairs cancer cell "missing self" recognition by NK cells. Oncoimmunology 2012, 1, 557-559. [CrossRef] [PubMed]

26. Nieswandt, B.; Hafner, M.; Echtenacher, B.; Mannel, D.N. Lysis of tumor cells by natural killer cells in mice is impeded by platelets. Cancer Res. 1999, 59, 1295-1300. [PubMed] 
27. Kopp, H.G.; Placke, T.; Salih, H.R. Platelet-derived transforming growth factor-beta down-regulates NKG2D thereby inhibiting natural killer cell antitumor reactivity. Cancer Res. 2009, 69, 7775-7783. [CrossRef] [PubMed]

28. Labelle, M.; Begum, S.; Hynes, R.O. Direct signaling between platelets and cancer cells induces an epithelial-mesenchymal-like transition and promotes metastasis. Cancer Cell 2011, 20, 576-590. [CrossRef] [PubMed]

29. Dardik, R.; Kaufmann, Y.; Savion, N.; Rosenberg, N.; Shenkman, B.; Varon, D. Platelets mediate tumor cell adhesion to the subendothelium under flow conditions: Involvement of platelet GPIIb-IIIa and tumor cell $\alpha(\mathrm{v})$ integrins. Int. J. Cancer 1997, 70, 201-207. [CrossRef]

30. Schumacher, D.; Strilic, B.; Sivaraj, K.K.; Wettschureck, N.; Offermanns, S. Platelet-derived nucleotides promote tumor-cell transendothelial migration and metastasis via P2Y2 receptor. Cancer Cell 2013, 24, 130-137. [CrossRef] [PubMed]

31. Sawicki, G.; Sanders, E.J.; Salas, E.; Wozniak, M.; Rodrigo, J.; Radomski, M.W. Localization and translocation of MMP-2 during aggregation of human platelets. Thromb. Haemost. 1998, 80, 836-839. [PubMed]

32. Choi, J.H.; Kim, H.; Kim, H.S.; Um, S.H.; Choi, J.W.; Oh, B.K. MMP-2 detective silicon nanowire biosensor using enzymatic cleavage reaction. J. Biomed. Nanotechnol. 2013, 9, 732-735. [CrossRef] [PubMed]

33. Gay, L.J.; Felding-Habermann, B. Contribution of platelets to tumour metastasis. Nat. Rev. Cancer 2011, 11, 123-134. [CrossRef] [PubMed]

34. Jurasz, P.; Alonso-Escolano, D.; Radomski, M.W. Platelet-Cancer interactions: Mechanisms and pharmacology of tumour cell-induced platelet aggregation. Br. J. Pharmacol. 2004, 143, 819-826. [CrossRef] [PubMed]

35. Erpenbeck, L.; Schon, M.P. Deadly allies: The fatal interplay between platelets and metastasizing cancer cells. Blood 2010, 115, 3427-3436. [CrossRef] [PubMed]

36. Varga-Szabo, D.; Pleines, I.; Nieswandt, B. Cell adhesion mechanisms in platelets. Arterioscler. Thromb. Vasc. Biol. 2008, 28, 403-412. [CrossRef] [PubMed]

37. Bennett, J.S. Regulation of integrins in platelets. Biopolymers 2015, 104, 323-333. [CrossRef] [PubMed]

38. Takagi, J.; Springer, T.A. Integrin activation and structural rearrangement. Immunol. Rev. 2002, 186, 141-163. [CrossRef] [PubMed]

39. Ruggeri, Z.M. Platelet adhesion under flow. Microcirculation 2009, 16, 58-83. [CrossRef] [PubMed]

40. Ruggeri, Z.M.; Mendolicchio, G.L. Adhesion mechanisms in platelet function. Circ. Res. 2007, 100, 1673-1685. [CrossRef] [PubMed]

41. Guidetti, G.F.; Canobbio, I.; Torti, M. PI3K/Akt in platelet integrin signaling and implications in thrombosis. Adv. Biol. Regul. 2015, 59, 36-52. [CrossRef] [PubMed]

42. Nieswandt, B.; Varga-Szabo, D.; Elvers, M. Integrins in platelet activation. J. Thromb. Haemost. 2009, 7, 206-209. [CrossRef] [PubMed]

43. Bianconi, D.; Unseld, M.; Prager, G.W. Integrins in the Spotlight of Cancer. Int. J. Mol. Sci. 2016, 17, 2037. [CrossRef] [PubMed]

44. Schaff, M.; Tang, C.; Maurer, E.; Bourdon, C.; Receveur, N.; Eckly, A.; Hechler, B.; Arnold, C.; de Arcangelis, A.; Nieswandt, B.; et al. Integrin $\alpha 6 \beta 1$ is the main receptor for vascular laminins and plays a role in platelet adhesion, activation, and arterial thrombosis. Circulation 2013, 128, 541-552. [CrossRef] [PubMed]

45. Zutter, M.M.; Santoro, S.A. Widespread histologic distribution of the $\alpha 2 \beta 1$ integrin cell-surface collagen receptor. Am. J. Pathol. 1990, 137, 113-120. [PubMed]

46. Madamanchi, A.; Santoro, S.A.; Zutter, M.M. $\alpha 2 \beta 1$ Integrin. Adv. Exp. Med. Biol. 2014, 819, 41-60. [CrossRef] [PubMed]

47. Langsenlehner, U.; Renner, W.; Yazdani-Biuki, B.; Eder, T.; Wascher, T.C.; Paulweber, B.; Clar, H.; Hofmann, G.; Samonigg, H.; Krippl, P. Integrin $\alpha 2$ and $\beta 3$ gene polymorphisms and breast cancer risk. Breast Cancer Res. Treat. 2006, 97, 67-72. [CrossRef] [PubMed]

48. Gerger, A.; Hofmann, G.; Langsenlehner, U.; Renner, W.; Weitzer, W.; Wehrschutz, M.; Wascher, T.; Samonigg, H.; Krippl, P. Integrin $\alpha 2$ and $\beta 3$ gene polymorphisms and colorectal cancer risk. Int. J. Colorectal Dis. 2009, 24, 159-163. [CrossRef] [PubMed]

49. Ayala, F.; Corral, J.; Gonzalez-Conejero, R.; Sanchez, I.; Moraleda, J.M.; Vicente, V. Genetic polymorphisms of platelet adhesive molecules: Association with breast cancer risk and clinical presentation. Breast Cancer Res. Treat. 2003, 80, 145-154. [CrossRef] [PubMed] 
50. Sarratt, K.L.; Chen, H.; Zutter, M.M.; Santoro, S.A.; Hammer, D.A.; Kahn, M.L. GPVI and $\alpha 2 \beta 1$ play independent critical roles during platelet adhesion and aggregate formation to collagen under flow. Blood 2005, 106, 1268-1277. [CrossRef] [PubMed]

51. Di Paola, J.; Jugessur, A.; Goldman, T.; Reiland, J.; Tallman, D.; Sayago, C.; Murray, J.C. Platelet glycoprotein $\mathrm{I}(\mathrm{b}) \alpha$ and integrin $\alpha 2 \beta 1$ polymorphisms: Gene frequencies and linkage disequilibrium in a population diversity panel. J. Thromb. Haemost. 2005, 3, 1511-1521. [CrossRef] [PubMed]

52. Inoue, O.; Suzuki-Inoue, K.; Dean, W.L.; Frampton, J.; Watson, S.P. Integrin $\alpha 2 \beta 1$ mediates outside-in regulation of platelet spreading on collagen through activation of Src kinases and PLCgamma2. J. Cell Biol. 2003, 160, 769-780. [CrossRef] [PubMed]

53. Kehrel, B.; Balleisen, L.; Kokott, R.; Mesters, R.; Stenzinger, W.; Clemetson, K.J.; van de Loo, J. Deficiency of intact thrombospondin and membrane glycoprotein Ia in platelets with defective collagen-induced aggregation and spontaneous loss of disorder. Blood 1988, 71, 1074-1078. [PubMed]

54. Nieuwenhuis, H.K.; Akkerman, J.W.; Houdijk, W.P.; Sixma, J.J. Human blood platelets showing no response to collagen fail to express surface glycoprotein Ia. Nature 1985, 318, 470-472. [CrossRef] [PubMed]

55. Holtkotter, O.; Nieswandt, B.; Smyth, N.; Muller, W.; Hafner, M.; Schulte, V.; Krieg, T.; Eckes, B. Integrin $\alpha 2$-deficient mice develop normally, are fertile, but display partially defective platelet interaction with collagen. J. Biol. Chem. 2002, 277, 10789-10794. [CrossRef] [PubMed]

56. He, L.; Pappan, L.K.; Grenache, D.G.; Li, Z.; Tollefsen, D.M.; Santoro, S.A.; Zutter, M.M. The contributions of the $\alpha 2 \beta 1$ integrin to vascular thrombosis in vivo. Blood 2003, 102, 3652-3657. [CrossRef] [PubMed]

57. Kuijpers, M.J.; Pozgajova, M.; Cosemans, J.M.; Munnix, I.C.; Eckes, B.; Nieswandt, B.; Heemskerk, J.W. Role of murine integrin $\alpha 2 \beta 1$ in thrombus stabilization and embolization: Contribution of thromboxane A2. Thromb. Haemost. 2007, 98, 1072-1080. [CrossRef] [PubMed]

58. Kunicki, T.J. The role of platelet collagen receptor (glycoprotein Ia/IIa; integrin $\alpha 2 \beta 1$ ) polymorphisms in thrombotic disease. Curr. Opin. Hematol. 2001, 8, 277-285. [CrossRef] [PubMed]

59. Kasirer-Friede, A.; Kahn, M.L.; Shattil, S.J. Platelet integrins and immunoreceptors. Immunol. Rev. 2007, 218, 247-264. [CrossRef] [PubMed]

60. Yang, J.T.; Rayburn, H.; Hynes, R.O. Embryonic mesodermal defects in $\alpha 5$ integrin-deficient mice. Development 1993, 119, 1093-1105. [PubMed]

61. Schaffner, F.; Ray, A.M.; Dontenwill, M. Integrin $\alpha 5 \beta 1$, the Fibronectin Receptor, as a Pertinent Therapeutic Target in Solid Tumors. Cancers 2013, 5, 27-47. [CrossRef] [PubMed]

62. Jung, A.C.; Ray, A.M.; Ramolu, L.; Macabre, C.; Simon, F.; Noulet, F.; Blandin, A.F.; Renner, G.; Lehmann, M.; Choulier, L.; et al. Caveolin-1-negative head and neck squamous cell carcinoma primary tumors display increased epithelial to mesenchymal transition and prometastatic properties. Oncotarget 2015, 6, 41884-41901. [CrossRef] [PubMed]

63. Bell-McGuinn, K.M.; Matthews, C.M.; Ho, S.N.; Barve, M.; Gilbert, L.; Penson, R.T.; Lengyel, E.; Palaparthy, R.; Gilder, K.; Vassos, A.; et al. A phase II, single-arm study of the anti- $\alpha 5 \beta 1$ integrin antibody volociximab as monotherapy in patients with platinum-resistant advanced epithelial ovarian or primary peritoneal cancer. Gynecol. Oncol. 2011, 121, 273-279. [CrossRef] [PubMed]

64. Beumer, S.; MJ, I.J.; de Groot, P.G.; Sixma, J.J. Platelet adhesion to fibronectin in flow: Dependence on surface concentration and shear rate, role of platelet membrane glycoproteins GP IIb/IIIa and VLA-5, and inhibition by heparin. Blood 1994, 84, 3724-3733. [PubMed]

65. Zaidi, T.N.; McIntire, L.V.; Farrell, D.H.; Thiagarajan, P. Adhesion of platelets to surface-bound fibrinogen under flow. Blood 1996, 88, 2967-2972. [PubMed]

66. McCarty, O.J.; Zhao, Y.; Andrew, N.; Machesky, L.M.; Staunton, D.; Frampton, J.; Watson, S.P. Evaluation of the role of platelet integrins in fibronectin-dependent spreading and adhesion. J. Thromb. Haemost. 2004, 2, 1823-1833. [CrossRef] [PubMed]

67. Maurer, E.; Schaff, M.; Receveur, N.; Bourdon, C.; Mercier, L.; Nieswandt, B.; Dubois, C.; Jandrot-Perrus, M.; Goetz, J.G.; Lanza, F.; et al. Fibrillar cellular fibronectin supports efficient platelet aggregation and procoagulant activity. Thromb. Haemost. 2015, 114, 1175-1188. [CrossRef] [PubMed]

68. Hallmann, R.; Horn, N.; Selg, M.; Wendler, O.; Pausch, F.; Sorokin, L.M. Expression and function of laminins in the embryonic and mature vasculature. Physiol. Rev. 2005, 85, 979-1000. [CrossRef] [PubMed] 
69. Georges-Labouesse, E.; Messaddeq, N.; Yehia, G.; Cadalbert, L.; Dierich, A.; Le Meur, M. Absence of integrin $\alpha 6$ leads to epidermolysis bullosa and neonatal death in mice. Nat. Genet. 1996, 13, 370-373. [CrossRef] [PubMed]

70. Hogg, N.; Bates, P.A. Genetic analysis of integrin function in man: LAD-1 and other syndromes. J. Int. Soc. Matrix Biol. 2000, 19, 211-222. [CrossRef]

71. Wewer, U.M.; Shaw, L.M.; Albrechtsen, R.; Mercurio, A.M. The integrin $\alpha 6 \beta 1$ promotes the survival of metastatic human breast carcinoma cells in mice. Am. J. Pathol. 1997, 151, 1191-1198. [PubMed]

72. Sroka, I.C.; Anderson, T.A.; McDaniel, K.M.; Nagle, R.B.; Gretzer, M.B.; Cress, A.E. The laminin binding integrin $\alpha 6 \beta 1$ in prostate cancer perineural invasion. J. Cell. Physiol. 2010, 224, 283-288. [CrossRef] [PubMed]

73. Lathia, J.D.; Gallagher, J.; Heddleston, J.M.; Wang, J.; Eyler, C.E.; Macswords, J.; Wu, Q.; Vasanji, A.; McLendon, R.E.; Hjelmeland, A.B.; et al. Integrin $\alpha 6$ regulates glioblastoma stem cells. Cell Stem Cell 2010, 6, 421-432. [CrossRef] [PubMed]

74. Lamb, L.E.; Zarif, J.C.; Miranti, C.K. The androgen receptor induces integrin $\alpha 6 \beta 1$ to promote prostate tumor cell survival via NF-kB and Bcl-xL Independently of PI3K signaling. Cancer Res. 2011, 71, 2739-2749. [CrossRef] [PubMed]

75. Ports, M.O.; Nagle, R.B.; Pond, G.D.; Cress, A.E. Extracellular engagement of $\alpha 6$ integrin inhibited urokinase-type plasminogen activator-mediated cleavage and delayed human prostate bone metastasis. Cancer Res. 2009, 69, 5007-5014. [CrossRef] [PubMed]

76. Hindriks, G.; Ijsseldijk, M.J.; Sonnenberg, A.; Sixma, J.J.; de Groot, P.G. Platelet adhesion to laminin: Role of $\mathrm{Ca}^{2+}$ and $\mathrm{Mg}^{2+}$ ions, shear rate, and platelet membrane glycoproteins. Blood 1992, 79, 928-935. [PubMed]

77. Inoue, O.; Suzuki-Inoue, K.; McCarty, O.J.; Moroi, M.; Ruggeri, Z.M.; Kunicki, T.J.; Ozaki, Y.; Watson, S.P. Laminin stimulates spreading of platelets through integrin $\alpha 6 \beta 1$-dependent activation of GPVI. Blood 2006, 107, 1405-1412. [CrossRef] [PubMed]

78. Sonnenberg, A.; Modderman, P.W.; Hogervorst, F. Laminin receptor on platelets is the integrin VLA-6. Nature 1988, 336, 487-489. [CrossRef] [PubMed]

79. Nigatu, A.; Sime, W.; Gorfu, G.; Geberhiwot, T.; Anduren, I.; Ingerpuu, S.; Doi, M.; Tryggvason, K.; Hjemdahl, P.; Patarroyo, M. Megakaryocytic cells synthesize and platelets secrete $\alpha 5$-laminins, and the endothelial laminin isoform laminin $10(\alpha 5 \beta 1 \gamma 1)$ strongly promotes adhesion but not activation of platelets. Thromb. Haemost. 2006, 95, 85-93. [CrossRef] [PubMed]

80. Geberhiwot, T.; Ingerpuu, S.; Pedraza, C.; Neira, M.; Lehto, U.; Virtanen, I.; Kortesmaa, J.; Tryggvason, K.; Engvall, E.; Patarroyo, M. Blood platelets contain and secrete laminin-8 ( $\alpha 4 \beta 1 \gamma 1)$ and adhere to laminin-8 via $\alpha 6 \beta 1$ integrin. Exp. Cell Res. 1999, 253, 723-732. [CrossRef] [PubMed]

81. Chang, J.C.; Chang, H.H.; Lin, C.T.; Lo, S.J. The integrin $\alpha 6 \beta 1$ modulation of PI3K and Cdc42 activities induces dynamic filopodium formation in human platelets. J. Biomed. Sci. 2005, 12, 881-898. [CrossRef] [PubMed]

82. Ill, C.R.; Engvall, E.; Ruoslahti, E. Adhesion of platelets to laminin in the absence of activation. J. Cell Biol. 1984, 99, 2140-2145. [CrossRef] [PubMed]

83. Pan, L.; Zhao, Y.; Yuan, Z.; Qin, G. Research advances on structure and biological functions of integrins. SpringerPlus 2016, 5, 1094. [CrossRef] [PubMed]

84. Grossi, I.M.; Hatfield, J.S.; Fitzgerald, L.A.; Newcombe, M.; Taylor, J.D.; Honn, K.V. Role of tumor cell glycoproteins immunologically related to glycoproteins $\mathrm{Ib}$ and $\mathrm{IIb} / \mathrm{III}$ in tumor cell-platelet and tumor cell-matrix interactions. FASEB J. 1988, 2, 2385-2395. [PubMed]

85. Honn, K.V.; Chen, Y.Q.; Timar, J.; Onoda, J.M.; Hatfield, J.S.; Fligiel, S.E.; Steinert, B.W.; Diglio, C.A.; Grossi, I.M.; Nelson, K.K.; et al. $\alpha \operatorname{Ilb} \beta 3$ integrin expression and function in subpopulations of murine tumors. Exp. Cell Res. 1992, 201, 23-32. [CrossRef]

86. Timar, J.; Trikha, M.; Szekeres, K.; Bazaz, R.; Honn, K. Expression and function of the high affinity $\alpha \mathrm{IIb} \beta 3$ integrin in murine melanoma cells. Clin. Exp. Metastasis 1998, 16, 437-445. [CrossRef] [PubMed]

87. Desgrosellier, J.S.; Cheresh, D.A. Integrins in cancer: Biological implications and therapeutic opportunities. Nat. Rev. Cancer 2010, 10, 9-22. [CrossRef] [PubMed]

88. Scatena, M.; Almeida, M.; Chaisson, M.L.; Fausto, N.; Nicosia, R.F.; Giachelli, C.M. NF-кB mediates $\alpha 3$ integrin-induced endothelial cell survival. J. Cell Biol. 1998, 141, 1083-1093. [CrossRef] [PubMed] 
89. Morimoto, K.; Satoh-Yamaguchi, K.; Hamaguchi, A.; Inoue, Y.; Takeuchi, M.; Okada, M.; Ikeda, W.; Takai, Y.; Imai, T. Interaction of cancer cells with platelets mediated by Necl-5/poliovirus receptor enhances cancer cell metastasis to the lungs. Oncogene 2008, 27, 264-273. [CrossRef] [PubMed]

90. Khan, Z.; Marshall, J.F. The role of integrins in TGF- $\beta$ activation in the tumour stroma. Cell Tissue Res. 2016, 365, 657-673. [CrossRef] [PubMed]

91. Nierodzik, M.L.; Kajumo, F.; Karpatkin, S. Effect of thrombin treatment of tumor cells on adhesion of tumor cells to platelets in vitro and tumor metastasis in vivo. Cancer Res. 1992, 52, 3267-3272. [PubMed]

92. Wagner, C.L.; Mascelli, M.A.; Neblock, D.S.; Weisman, H.F.; Coller, B.S.; Jordan, R.E. Analysis of GPIIb/IIIa receptor number by quantification of 7E3 binding to human platelets. Blood 1996, 88, 907-914. [PubMed]

93. Nurden, A.T. Glanzmann thrombasthenia. Orphanet J. Rare Dis. 2006, 1, 10. [CrossRef] [PubMed]

94. Yousuf, O.; Bhatt, D.L. The evolution of antiplatelet therapy in cardiovascular disease. Nat. Rev. Cardiol. 2011, 8, 547-559. [CrossRef] [PubMed]

95. Watson, S.P.; Auger, J.M.; McCarty, O.J.; Pearce, A.C. GPVI and integrin $\alpha \mathrm{IIb} \beta 3$ signaling in platelets. J. Thromb. Haemost. 2005, 3, 1752-1762. [CrossRef] [PubMed]

96. Zhang, G.; Xiang, B.; Ye, S.; Chrzanowska-Wodnicka, M.; Morris, A.J.; Gartner, T.K.; Whiteheart, S.W.; White, G.C., 2nd; Smyth, S.S.; Li, Z. Distinct roles for Rap1b protein in platelet secretion and integrin $\alpha \mathrm{IIb} \beta 3$ outside-in signaling. J. Biol. Chem. 2011, 286, 39466-39477. [CrossRef] [PubMed]

97. Goschnick, M.W.; Lau, L.M.; Wee, J.L.; Liu, Y.S.; Hogarth, P.M.; Robb, L.M.; Hickey, M.J.; Wright, M.D.; Jackson, D.E. Impaired "outside-in" integrin $\alpha \mathrm{IIb} \beta 3$ signaling and thrombus stability in TSSC6-deficient mice. Blood 2006, 108, 1911-1918. [CrossRef] [PubMed]

98. Law, D.A.; DeGuzman, F.R.; Heiser, P.; Ministri-Madrid, K.; Killeen, N.; Phillips, D.R. Integrin cytoplasmic tyrosine motif is required for outside-in $\alpha \operatorname{Ilb} \beta 3$ signalling and platelet function. Nature 1999, 401, 808-811. [CrossRef] [PubMed]

99. Phillips, D.R.; Prasad, K.S.; Manganello, J.; Bao, M.; Nannizzi-Alaimo, L. Integrin tyrosine phosphorylation in platelet signaling. Curr. Opin. Cell Biol. 2001, 13, 546-554. [CrossRef]

100. Takizawa, H.; Nishimura, S.; Takayama, N.; Oda, A.; Nishikii, H.; Morita, Y.; Kakinuma, S.; Yamazaki, S.; Okamura, S.; Tamura, N.; et al. Lnk regulates integrin $\alpha \mathrm{Ilb} \beta 3$ outside-in signaling in mouse platelets, leading to stabilization of thrombus development in vivo. J. Clin. Investig. 2010, 120, 179-190. [CrossRef] [PubMed]

101. Valiyaveettil, M.; Kar, N.; Ashraf, M.Z.; Byzova, T.V.; Febbraio, M.; Podrez, E.A. Oxidized high-density lipoprotein inhibits platelet activation and aggregation via scavenger receptor BI. Blood 2008, 111, 1962-1971. [CrossRef] [PubMed]

102. Paul, B.Z.; Vilaire, G.; Kunapuli, S.P.; Bennett, J.S. Concurrent signaling from Galphaq- and Galphai-coupled pathways is essential for agonist-induced $\alpha \mathrm{v} \beta 3$ activation on human platelets. J. Thromb. Haemost. 2003, 1, 814-820. [CrossRef] [PubMed]

103. Mor-Cohen, R. Disulfide Bonds as Regulators of Integrin Function in Thrombosis and Hemostasis. Antioxid. Redox Signal. 2016, 24, 16-31. [CrossRef] [PubMed]

104. Mahimkar, R.M.; Visaya, O.; Pollock, A.S.; Lovett, D.H. The disintegrin domain of ADAM9: A ligand for multiple beta1 renal integrins. Biochem. J. 2005, 385, 461-468. [CrossRef] [PubMed]

105. Karpatkin, S.; Pearlstein, E.; Ambrogio, C.; Coller, B.S. Role of adhesive proteins in platelet tumor interaction in vitro and metastasis formation in vivo. J. Clin. Investig. 1988, 81, 1012-1019. [CrossRef] [PubMed]

106. Nierodzik, M.L.; Plotkin, A.; Kajumo, F.; Karpatkin, S. Thrombin stimulates tumor-platelet adhesion in vitro and metastasis in vivo. J. Clin. Investig. 1991, 87, 229-236. [CrossRef] [PubMed]

107. Qian, W.; Tao, L.; Wang, Y.; Zhang, F.; Li, M.; Huang, S.; Wang, A.; Chen, W.; Yue, Z.; Chen, L.; et al. Downregulation of Integrins in Cancer Cells and Anti-Platelet Properties Are Involved in Holothurian Glycosaminoglycan-Mediated Disruption of the Interaction of Cancer Cells and Platelets in Hematogenous Metastasis. J. Vasc. Res. 2015, 52, 197-209. [CrossRef] [PubMed]

108. Chopra, H.; Hatfield, J.S.; Chang, Y.S.; Grossi, I.M.; Fitzgerald, L.A.; O'Gara, C.Y.; Marnett, L.J.; Diglio, C.A.; Taylor, J.D.; Honn, K.V. Role of tumor cytoskeleton and membrane glycoprotein IRGpIIb/IIIa in platelet adhesion to tumor cell membrane and tumor cell-induced platelet aggregation. Cancer Res. 1988, 48, 3787-3800. [PubMed]

109. Humphries, M.J.; Yamada, K.M.; Olden, K. Investigation of the biological effects of anti-cell adhesive synthetic peptides that inhibit experimental metastasis of B16-F10 murine melanoma cells. J. Clin. Investig. 1988, 81, 782-790. [CrossRef] [PubMed] 
110. McCarty, O.J.; Mousa, S.A.; Bray, P.F.; Konstantopoulos, K. Immobilized platelets support human colon carcinoma cell tethering, rolling, and firm adhesion under dynamic flow conditions. Blood 2000, 96, 1789-1797. [PubMed]

111. Gawaz, M.P.; Loftus, J.C.; Bajt, M.L.; Frojmovic, M.M.; Plow, E.F.; Ginsberg, M.H. Ligand bridging mediates integrin $\alpha \mathrm{IIb} \beta 3$ (platelet GPIIB-IIIA) dependent homotypic and heterotypic cell-cell interactions. J. Clin. Investig. 1991, 88, 1128-1134. [CrossRef] [PubMed]

112. Zhang, C.; Liu, Y.; Gao, Y.; Shen, J.; Zheng, S.; Wei, M.; Zeng, X. Modified heparins inhibit integrin $\alpha(\mathrm{IIb}) \beta(3)$ mediated adhesion of melanoma cells to platelets in vitro and in vivo. Int. J. Cancer 2009, 125, 2058-2065. [CrossRef] [PubMed]

113. Lonsdorf, A.S.; Kramer, B.F.; Fahrleitner, M.; Schonberger, T.; Gnerlich, S.; Ring, S.; Gehring, S.; Schneider, S.W.; Kruhlak, M.J.; Meuth, S.G.; et al. Engagement of $\alpha \operatorname{Ilb} \beta 3$ (GPIIb/IIIa) with $\alpha v \beta 3$ integrinD mediates interaction of melanoma cells with platelets: A connection to hematogenous metastasis. J. Biol. Chem. 2012, 287, 2168-2178. [CrossRef] [PubMed]

114. Bastida, E.; Escolar, G.; Almirall, L.; Ordinas, A. Platelet activation induced by a human neuroblastoma tumor cell line is reduced by prior administration of ticlopidine. Thromb. Haemost. 1986, 55, 333-337. [PubMed]

115. Heinmoller, E.; Weinel, R.J.; Heidtmann, H.H.; Salge, U.; Seitz, R.; Schmitz, I.; Muller, K.M.; Zirngibl, H. Studies on tumor-cell-induced platelet aggregation in human lung cancer cell lines. J. Cancer Res. Clin. Oncol. 1996, 122, 735-744. [CrossRef] [PubMed]

116. Boukerche, H.; Berthier-Vergnes, O.; Penin, F.; Tabone, E.; Lizard, G.; Bailly, M.; McGregor, J.L. Human melanoma cell lines differ in their capacity to release ADP and aggregate platelets. Br. J. Haematol. 1994, 87, 763-772. [CrossRef] [PubMed]

117. Alonso-Escolano, D.; Strongin, A.Y.; Chung, A.W.; Deryugina, E.I.; Radomski, M.W. Membrane type-1 matrix metalloproteinase stimulates tumour cell-induced platelet aggregation: Role of receptor glycoproteins. Br. J. Pharmacol. 2004, 141, 241-252. [CrossRef] [PubMed]

118. Jurasz, P.; Sawicki, G.; Duszyk, M.; Sawicka, J.; Miranda, C.; Mayers, I.; Radomski, M.W. Matrix metalloproteinase 2 in tumor cell-induced platelet aggregation: Regulation by nitric oxide. Cancer Res. 2001, 61, 376-382. [PubMed]

119. Grignani, G.; Pacchiarini, L.; Almasio, P.; Pagliarino, M.; Gamba, G.; Rizzo, S.C.; Ascari, E. Characterization of the platelet-aggregating activity of cancer cells with different metastatic potential. Int. J. Cancer 1986, 38, 237-244. [CrossRef] [PubMed]

120. Pacchiarini, L.; Zucchella, M.; Milanesi, G.; Tacconi, F.; Bonomi, E.; Canevari, A.; Grignani, G. Thromboxane production by platelets during tumor cell-induced platelet activation. Invasion Metastasis 1991, 11, 102-109. [PubMed]

121. Tzanakakis, G.N.; Krambovitis, E.; Tsatsakis, A.M.; Vezeridis, M.P. The preventive effect of ketoconazole on experimental metastasis from a human pancreatic carcinoma may be related to its effect on prostaglandin synthesis. Int. J. Gastrointest. Cancer 2002, 32, 23-30. [CrossRef]

122. De Leval, X.; Benoit, V.; Delarge, J.; Julemont, F.; Masereel, B.; Pirotte, B.; Merville, M.P.; David, J.L.; Dogne, J.M. Pharmacological evaluation of the novel thromboxane modulator BM-567 (II/II). Effects of BM-567 on osteogenic sarcoma-cell-induced platelet aggregation. Prostaglandins Leukot. Essent. Fat. Acids 2003, 68, 55-59. [CrossRef]

123. Steinert, B.W.; Tang, D.G.; Grossi, I.M.; Umbarger, L.A.; Honn, K.V. Studies on the role of platelet eicosanoid metabolism and integrin $\alpha \mathrm{IIb} \beta 3$ in tumor-cell-induced platelet aggregation. Int. J. Cancer 1993, 54, 92-101. [CrossRef] [PubMed]

124. Amirkhosravi, A.; Amaya, M.; Siddiqui, F.; Biggerstaff, J.P.; Meyer, T.V.; Francis, J.L. Blockade of GpIIb/IIIa inhibits the release of vascular endothelial growth factor (VEGF) from tumor cell-activated platelets and experimental metastasis. Platelets 1999, 10, 285-292. [CrossRef] [PubMed]

125. Bastida, E.; Almirall, L.; Jamieson, G.A.; Ordinas, A. Cell surface sialylation of two human tumor cell lines and its correlation with their platelet-activating activity. Cancer Res. 1987, 47, 1767-1770. [PubMed]

126. Grossi, I.M.; Fitzgerald, L.A.; Kendall, A.; Taylor, J.D.; Sloane, B.F.; Honn, K.V. Inhibition of human tumor cell induced platelet aggregation by antibodies to platelet glycoproteins Ib and IIb/IIIa. Proc. Soc. Exp. Biol. Med. 1987, 186, 378-383. [CrossRef] [PubMed] 
127. Sheu, J.R.; Lin, C.H.; Chung, J.L.; Teng, C.M.; Huang, T.F. Triflavin, an Arg-Gly-Asp containing snake venom peptide, inhibits aggregation of human platelets induced by human hepatoma cell line. Thromb. Res. 1992, 66, 679-691. [CrossRef]

128. Sheu, J.R.; Lin, C.H.; Peng, H.C.; Teng, C.M.; Huang, T.F. Triflavin, an Arg-Gly-Asp-containing peptide, inhibits tumor cell-induced platelet aggregation. Jpn. J. Cancer Res. 1993, 84, 1062-1071. [CrossRef] [PubMed]

129. Lian, L.; Li, W.; Li, Z.Y.; Mao, Y.X.; Zhang, Y.T.; Zhao, Y.M.; Chen, K.; Duan, W.M.; Tao, M. Inhibition of MCF-7 breast cancer cell-induced platelet aggregation using a combination of antiplatelet drugs. Oncol. Lett. 2013, 5, 675-680. [CrossRef] [PubMed]

130. Bastida, E.; Almirall, L.; Ordinas, A. Tumor-cell-induced platelet aggregation is a glycoprotein-dependent and lipoxygenase-associated process. Int. J. Cancer 1987, 39, 760-763. [CrossRef] [PubMed]

131. Chang, Y.W.; Hsieh, P.W.; Chang, Y.T.; Lu, M.H.; Huang, T.F.; Chong, K.Y.; Liao, H.R.; Cheng, J.C.; Tseng, C.P. Identification of a novel platelet antagonist that binds to CLEC-2 and suppresses podoplanin-induced platelet aggregation and cancer metastasis. Oncotarget 2015, 6, 42733-42748. [CrossRef] [PubMed]

132. Hamilton, C.A.; Deighton, N.M.; Jones, C.R.; Reid, J.L. Changes in rabbit platelet $\alpha$ and $\beta$ adrenoceptor number and platelet aggregation. Eur. J. Pharmacol. 1986, 130, 145-149. [CrossRef]

133. Oleksowicz, L.; Mrowiec, Z.; Schwartz, E.; Khorshidi, M.; Dutcher, J.P.; Puszkin, E. Characterization of tumor-induced platelet aggregation: The role of immunorelated GPIb and GPIIb/IIIa expression by MCF-7 breast cancer cells. Thromb. Res. 1995, 79, 261-274. [CrossRef]

134. Cavanaugh, P.G.; Sloane, B.F.; Honn, K.V. Role of the coagulation system in tumor-cell-induced platelet aggregation and metastasis. Haemostasis 1988, 18, 37-46. [CrossRef] [PubMed]

135. Jung, G.; Millon-Collard, R.; Abecassis, J. Procoagulant and aggregating platelet activities of human mammary tumor cells. Bull. Cancer 1991, 78, 253-260. [PubMed]

136. Pacchiarini, L.; Zucchella, M.; Eynard, A.R.; Grignani, G. Tumor cells induce platelet aggregation and intraplatelet calcium ion movements. Platelets 1993, 4, 275-279. [CrossRef] [PubMed]

137. Heinmoller, E.; Schropp, T.; Kisker, O.; Simon, B.; Seitz, R.; Weinel, R.J. Tumor cell-induced platelet aggregation in vitro by human pancreatic cancer cell lines. Scand. J. Gastroenterol. 1995, 30, 1008-1016. [CrossRef] [PubMed]

138. Sugimoto, Y.; Watanabe, M.; Oh-hara, T.; Sato, S.; Isoe, T.; Tsuruo, T. Suppression of experimental lung colonization of a metastatic variant of murine colon adenocarcinoma 26 by a monoclonal antibody 8 F11 inhibiting tumor cell-induced platelet aggregation. Cancer Res. 1991, 51, 921-925. [PubMed]

139. Okoshi, H.; Hakomori, S.; Nisar, M.; Zhou, Q.H.; Kimura, S.; Tashiro, K.; Igarashi, Y. Cell membrane signaling as target in cancer therapy. II: Inhibitory effect of N,N,N-trimethylsphingosine on metastatic potential of murine B16 melanoma cell line through blocking of tumor cell-dependent platelet aggregation. Cancer Res. 1991, 51, 6019-6024. [PubMed]

140. Mahalingam, M.; Ugen, K.E.; Kao, K.J.; Klein, P.A. Functional role of platelets in experimental metastasis studied with cloned murine fibrosarcoma cell variants. Cancer Res. 1988, 48, 1460-1464. [PubMed]

141. Tang, D.G.; Onoda, J.M.; Steinert, B.W.; Grossi, I.M.; Nelson, K.K.; Umbarger, L.; Diglio, C.A.; Taylor, J.D.; Honn, K.V. Phenotypic properties of cultured tumor cells: Integrin $\alpha \mathrm{Ilb} \beta 3$ expression, tumor-cell-induced platelet aggregation, and tumor-cell adhesion to endothelium as important parameters of experimental metastasis. Int. J. Cancer 1993, 54, 338-347. [CrossRef] [PubMed]

142. Medina, C.; Jurasz, P.; Santos-Martinez, M.J.; Jeong, S.S.; Mitsky, T.; Chen, R.; Radomski, M.W. Platelet aggregation-induced by caco-2 cells: Regulation by matrix metalloproteinase-2 and adenosine diphosphate. J. Pharmacol. Exp. Ther. 2006, 317, 739-745. [CrossRef] [PubMed]

143. Kunita, A.; Kashima, T.G.; Morishita, Y.; Fukayama, M.; Kato, Y.; Tsuruo, T.; Fujita, N. The platelet aggregation-inducing factor aggrus/podoplanin promotes pulmonary metastasis. Am. J. Pathol. 2007, 170, 1337-1347. [CrossRef] [PubMed]

144. Kim, S.D.; Lee, Y.J.; Baik, J.S.; Han, J.Y.; Lee, C.G.; Heo, K.; Park, Y.S.; Kim, J.S.; Ji, H.D.; Park, S.I.; et al. Baicalein inhibits agonist- and tumor cell-induced platelet aggregation while suppressing pulmonary tumor metastasis via cAMP-mediated VASP phosphorylation along with impaired MAPKs and PI3K-Akt activation. Biochem. Pharmacol. 2014, 92, 251-265. [CrossRef] [PubMed]

145. Amirkhosravi, A.; Mousa, S.A.; Amaya, M.; Blaydes, S.; Desai, H.; Meyer, T.; Francis, J.L. Inhibition of tumor cell-induced platelet aggregation and lung metastasis by the oral GpIIb/IIIa antagonist XV454. Thromb. Haemost. 2003, 90, 549-554. [CrossRef] [PubMed] 
146. Bakewell, S.J.; Nestor, P.; Prasad, S.; Tomasson, M.H.; Dowland, N.; Mehrotra, M.; Scarborough, R.; Kanter, J.; Abe, K.; Phillips, D.; et al. Platelet and osteoclast $\beta 3$ integrins are critical for bone metastasis. Proc. Nat. Acad. Sci. USA 2003, 100, 14205-14210. [CrossRef] [PubMed]

147. Zhang, W.; Dang, S.; Hong, T.; Tang, J.; Fan, J.; Bu, D.; Sun, Y.; Wang, Z.; Wisniewski, T. A humanized single-chain antibody against $\beta 3$ integrin inhibits pulmonary metastasis by preferentially fragmenting activated platelets in the tumor microenvironment. Blood 2012, 120, 2889-2898. [CrossRef] [PubMed]

148. Trikha, M.; Zhou, Z.; Timar, J.; Raso, E.; Kennel, M.; Emmell, E.; Nakada, M.T. Multiple roles for platelet GPIIb/IIIa and $\alpha \mathrm{v} \beta 3$ integrins in tumor growth, angiogenesis, and metastasis. Cancer Res. 2002, 62, 2824-2833. [PubMed]

149. Schror, K.; Weber, A.A. Comparative pharmacology of GP IIb/IIIa antagonists. J. Thromb. Haemost. 2003, 15, 71-80. [CrossRef]

150. Echtler, K.; Konrad, I.; Lorenz, M.; Schneider, S.; Hofmaier, S.; Plenagl, F.; Stark, K.; Czermak, T.; Tirniceriu, A.; Eichhorn, M.; et al. Platelet GPIIb supports initial pulmonary retention but inhibits subsequent proliferation of melanoma cells during hematogenic metastasis. PloS ONE 2017, 12, e0172788. [CrossRef] [PubMed]

151. Ugen, K.E.; Mahalingam, M.; Klein, P.A.; Kao, K.J. Inhibition of tumor cell-induced platelet aggregation and experimental tumor metastasis by the synthetic Gly-Arg-Gly-Asp-Ser peptide. J. Nat. Cancer Inst. 1988, 80, 1461-1466. [CrossRef] [PubMed]

152. Soszka, T.; Knudsen, K.A.; Beviglia, L.; Rossi, C.; Poggi, A.; Niewiarowski, S. Inhibition of murine melanoma cell-matrix adhesion and experimental metastasis by albolabrin, an RGD-containing peptide isolated from the venom of Trimeresurus albolabris. Exp. Cell Res. 1991, 196, 6-12. [CrossRef]

153. Schneider, D.J. Anti-platelet therapy: Glycoprotein IIb-IIIa antagonists. Br. J. Clin. Pharmacol. 2011, 72, 672-682. [CrossRef] [PubMed]

154. Chew, D.P.; Bhatt, D.L.; Sapp, S.; Topol, E.J. Increased mortality with oral platelet glycoprotein IIb/IIIa antagonists: A meta-analysis of phase III multicenter randomized trials. Circulation 2001, 103, 201-206. [CrossRef] [PubMed]

155. Bassler, N.; Loeffler, C.; Mangin, P.; Yuan, Y.; Schwarz, M.; Hagemeyer, C.E.; Eisenhardt, S.U.; Ahrens, I.; Bode, C.; Jackson, S.P.; et al. A mechanistic model for paradoxical platelet activation by ligand-mimetic

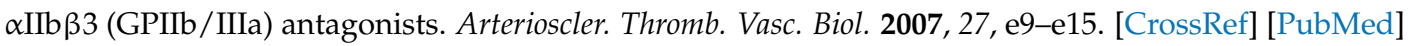

156. Hagemeyer, C.E.; Peter, K. Targeting the platelet integrin GPIIb/IIIa. Curr. Pharm. Des. 2010, 16, 4119-4133. [CrossRef] [PubMed]

157. Armstrong, P.C.; Peter, K. GPIIb/IIIa inhibitors: From bench to bedside and back to bench again. Thromb. Haemost. 2012, 107, 808-814. [CrossRef] [PubMed]

158. Schwarz, M.; Meade, G.; Stoll, P.; Ylanne, J.; Bassler, N.; Chen, Y.C.; Hagemeyer, C.E.; Ahrens, I.; Moran, N.; Kenny, D.; et al. Conformation-specific blockade of the integrin GPIIb/IIIa: A novel antiplatelet strategy that selectively targets activated platelets. Circ. Res. 2006, 99, 25-33. [CrossRef] [PubMed]

159. Li, J.; Vootukuri, S.; Shang, Y.; Negri, A.; Jiang, J.K.; Nedelman, M.; Diacovo, T.G.; Filizola, M.; Thomas, C.J.; Coller, B.S. RUC-4: A novel $\alpha \mathrm{Ilb} \beta 3$ antagonist for prehospital therapy of myocardial infarction. Arterioscler. Thromb. Vasc. Biol. 2014, 34, 2321-2329. [CrossRef] [PubMed]

160. Zhu, G.; Zhang, Q.; Reddy, E.C.; Carrim, N.; Chen, Y.; Xu, X.R.; Xu, M.; Wang, Y.; Hou, Y.; Ma, L.; et al. The integrin PSI domain has an endogenous thiol isomerase function and is a novel target for antiplatelet therapy. Blood 2017, 129, 1840-1854. [CrossRef] [PubMed]

(C) 2017 by the authors. Licensee MDPI, Basel, Switzerland. This article is an open access article distributed under the terms and conditions of the Creative Commons Attribution (CC BY) license (http://creativecommons.org/licenses/by/4.0/). 